\title{
The Importance of Nutrient Management for Potato Production Part I: Plant Nutrition and Yield
}

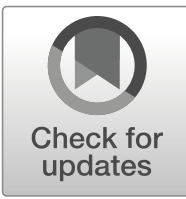

\section{Mirjam Koch ${ }^{1} \cdot$ Marcel Naumann $^{1} \cdot$ Elke Pawelzik $^{1}$ (D) Andreas Gransee ${ }^{2} \cdot$ Heike Thiel $^{2}$}

Received: 12 May 2017 / Accepted: 9 July 2019/

Published online: 5 August 2019

(C) The Author(s) 2019

\begin{abstract}
As part of a successful agronomic strategy, adequate nutrient management of the potato crop is essential throughout the whole growth period. In this review, the importance of balanced fertilisation for potato yield formation and yield security is addressed by taking advantage of the results of field trials and existing literature. The most important roles of the macronutrients nitrogen, phosphorous, potassium, magnesium, calcium and sulphur in the plant and their importance for yield formation in potato are reviewed. Fertilisation practices in potato production are discussed. Due to their various functions in plant metabolism, the impact of plant nutrients on potato yield is complex. Therefore, interactions with abiotic and biotic factors, for instance interactions between two different plant nutrients in the soil and the plant, are taken into account.
\end{abstract}

Keywords Magnesium · Nitrogen · Phosphorous $\cdot$ Potassium $\cdot$ Potato $\cdot$ Productivity $\cdot$ Yield

\section{Introduction}

Potato (Solanum tuberosum L.) is a highly attractive crop in agricultural production systems since it combines an extraordinarily high yield potential with a high nutritional value. However, while countries with a high-input agriculture, such as the USA, France and Germany, can reach average potato yields of more than $45 \mathrm{t} \mathrm{ha}^{-1}$ (Table 1), the average yields of most other countries are considerably lower leading to average potato yields of $20 \mathrm{t} \mathrm{ha}^{-1}$ worldwide (Table 1). Potatoes are a good source of energy, minerals,

Elke Pawelzik

epawelz@gwdg.de

1 Quality of Plant Products, Department of Crop Sciences, Faculty of Agricultural Sciences,

University of Goettingen, Carl-Sprengel-Weg 1, 37075 Goettingen, Germany

$2 \mathrm{~K}+\mathrm{S}$ KALI GmbH, Bertha-von-Suttner-Str. 7, 34131 Kassel, Germany 
Table 1 Potato production details from Europe, America, Asia and Africa in total plus top five countries according to the cultivation area, the amount of harvested product, and the average yield in 1997 and 2017

\begin{tabular}{|c|c|c|c|c|c|c|c|}
\hline \multirow[t]{2}{*}{ Country } & \multicolumn{2}{|c|}{ Harvest area $(\mathrm{ha})^{*}$} & \multicolumn{2}{|l|}{ Quantity (t)* } & \multicolumn{2}{|c|}{ Average yield $(\mathrm{t} / \mathrm{ha})^{*}$} & \\
\hline & 1997 & 2017 & 1997 & 2017 & 1997 & 2017 & \\
\hline Russia $^{1}$ & $3,154,351$ & $1,889,208$ & $35,137,578$ & $29,589,976$ & 11.1 & 15.7 & Europe \\
\hline Ukraine & $1,577,400$ & $1,323,200$ & $16,700,800$ & $22,208,220$ & 10.6 & 16.8 & \\
\hline Germany & 303,584 & 250,500 & $11,659,284$ & $11,720,000$ & 38.4 & 46.8 & \\
\hline Poland & $1,306,442$ & 329,323 & $20,775,644$ & $9,171,733$ & 15.5 & 27.9 & \\
\hline Netherlands & 179,900 & 160,791 & $7,973,000$ & $7,391,881$ & 44.3 & 46.0 & \\
\hline Total & $9,163,046$ & $5,365,045$ & $141,542,970$ & $121,761,565$ & 15.4 & 22.7 & \\
\hline $\mathrm{USA}^{2}$ & 547,780 & 415,010 & $21,186,890$ & $20,017,350$ & 38.7 & 48.2 & America \\
\hline Peru & 248,546 & 310,400 & $2,403,510$ & $4,776,294$ & 9.7 & 15.4 & \\
\hline Canada & 375,900 & 342,218 & $4,179,818$ & $4,410,829$ & 11.1 & 12.9 & \\
\hline Brazil & 174,830 & 118,030 & $2,670,493$ & $3,656,846$ & 15.3 & 31.0 & \\
\hline Colombia & 166,765 & 149,060 & $2,716,997$ & $2,819,026$ & 16.3 & 18.9 & \\
\hline Total & $2,014,575$ & $1,797,479$ & $40,998,690$ & $44,173,458$ & 20.4 & 24.6 & \\
\hline China $^{3}$ & $3,823,960$ & $5,765,144$ & $57,207,500$ & $99,147,000$ & 15.0 & 17.2 & Asia \\
\hline India & $1,248,800$ & $2,179,000$ & $24,215,900$ & $48,605,000$ & 19.4 & 22.3 & \\
\hline Bangladesh & 133,971 & 499,725 & $1,507,860$ & $10,215,957$ & 11.3 & 20.4 & \\
\hline Iran & 157,811 & 160,902 & $3,284,106$ & $5,102,342$ & 20.8 & 31.7 & \\
\hline Turkey & 210,900 & 142,851 & $5,100,000$ & $4,800,000$ & 24.2 & 33.6 & \\
\hline Total & $6,663,374$ & $10,209,139$ & $106,284,490$ & $195,668,682$ & 16.0 & 19.2 & \\
\hline Algeria & 67,180 & 148,692 & 947,518 & $4,606,403$ & 14.1 & 31.0 & Africa \\
\hline Egypt & 82,561 & 163,939 & $1,802,761$ & $4,325,478$ & 21.8 & 26.4 & \\
\hline South Africa & 55,973 & 67,746 & $1,579,021$ & $2,450,541$ & 28.2 & 36.2 & \\
\hline Morocco & 66,400 & 64,293 & $1,186,610$ & $1,924,871$ & 17.9 & 30.0 & \\
\hline Tanzania & 74,557 & 211,927 & 545,200 & $1,749,213$ & 7.3 & 8.3 & \\
\hline Total & 906,231 & $1,892,633$ & $10,514,203$ & $25,011,823$ & 11.6 & 13.2 & \\
\hline World & $18,798,740$ & $19,302,642$ & $301,079,129$ & $388,190,674$ & 16.0 & 20.1 & \\
\hline
\end{tabular}

${ }^{1}$ Russian Federation, ${ }^{2}$ United States of America, ${ }^{3}$ China, mainland

*All data were taken and re-calculated from faostat (http://faostat3.fao.org)

proteins, fats and vitamins (Ekin 2011; Drewnowski and Rehm 2013; King and Slavin 2013). Besides, potatoes are not just an important food source (Andre et al. 2014). They are also increasingly serving as feedstock for industrial products (Izmirlioglu and Demirci 2015; Jagatee et al. 2015). Therefore, unlike most other crops, potatoes have an unusually high range of utilisation possibilities, which makes their production even more attractive.

The yield of a potato crop is mainly determined by its specific genetic background (Evans and Fischer 1999). There is a gap between the actual yield and the yield potential (Van Keulen and Stol 1995; Michel et al. 2015). According to the yield potential concept, the potential yield is never fully reached in natural production systems as biotic and abiotic factors interfere with the potato crop negatively and affect 
plant growth and tuber development. Important biotic stress factors in potato production include late blight (Phytophthora infestans) (Nowicki et al. 2012) and fungal infections, such as early blight (Alternari solani), silver scurf (Helminthosporium solani) and black scurf (Rhizoctonia solani), as well as Fusarium and Verticillium wilt (Rich 1983). Furthermore, other kinds of pathogens such as plant parasitic nematodes can affect potato yield and production. The white potato cyst nematode (Globodera pallida) and the yellow potato cyst nematode (Globodera rostochiensis) are the main economically important nematode species (Eves-van den Akker et al. 2016). Besides, various bacterial and viral diseases affect potato yield and production (Rich 1983). The abiotic stresses that reduce yield include high radiation (Jansen 2002), heat stress (Herman et al. 2017), cold stress (Oufir et al. 2008) and air pollutants such as nitrogen dioxide and ozone (Bahl and Kahl 1995). The most important abiotic factor affecting yield and quality is drought stress (Obidiegwu et al. 2015).

To a certain degree, growers can reduce the negative effects of the environmental impacts by using balanced agronomic management strategies. Apart from the choice of cultivar, plant protection and continuous water supply, a further important agronomic measure for potato production is adequate nutrient management (Table 2). A sufficient supply of mineral nutrients (1) can fortify the potato plant against adverse growth conditions, (2) is crucial for achieving high yield and (3) is essential for producing potatoes that meet the desired quality requirements.

At the end of the nineteenth century and at the beginning of the twentieth century, a lot of effort was put into investigating the relationships between production factors, such as the nutrient supply of the plant, and the yield of crops (De Wit 1994). The most famous yield-response law originating from this time is the law of the minimum developed by Carl Sprengel and, later, spread by Justus von Liebig in the early nineteenth century. According to the law of the minimum, optimal crop growth can take place only if all required nutrients are at the optimum level (Sprengel 1828; von Liebig 1840, 1855; cited in van der Ploeg et al. 1999). In detail, it states that plant growth is controlled not by the total amount of nutrients available but by the amount of the scarcest nutrient. This law points to the importance of balanced nutrition for optimal plant growth. The law of diminishing yield increase formulated first by Eilhard Alfred Mitscherlich (McNall 1933) is of similar importance. This law states that the higher the nutrient supply the lower the yield increase obtained from increase in fertilisation, which means that yield response to fertilisation follows a saturation curve (Spillman 1923). A further law is the law of the optimum formulated by Georg Liebscher. Liebscher stated that the production factor, which is in minimum supply, contributes more to yield (production) increase the closer the other production factors are to their optimum (Liebscher 1895; cited in Nijland et al. 2008). These laws are the basis for modern approaches to develop strategies for efficient resource use in plant production. Based on the emerging challenges in modern agriculture, De Wit (1992) suggested that the laws developed by Liebig, Mitscherlich and Liebscher could be used as particular alternatives in one dynamic model. He concluded that both agriculture and environment should focus towards the minimum of production resources that are necessary for maximum use of other resources (De Wit 1992). Although many studies about the role, the nutrient uptake and the removal of nutrients by cereal crops are available, for the potato crop they rely mainly on data produced decades ago, indicating a need for further studies. 
Table 2 Fertilisation recommendations of different production areas in Europe, South Africa and India (shown are the locally recommended amounts of nutrients for potato production derived from the regionspecific fertilisation recommendation system; the procedure applied to develop a fertilisation recommendation differs among regions)

\begin{tabular}{|c|c|c|c|c|c|c|}
\hline \multirow[t]{2}{*}{ Country/region } & \multirow[t]{2}{*}{ Soil type } & \multicolumn{5}{|c|}{ Recommended fertilisation dose $\left(\mathrm{kg} \mathrm{ha}^{-1}\right)$} \\
\hline & & $\mathrm{N}$ & $\mathrm{P}_{2} \mathrm{O}_{5}$ & $\mathrm{~K}_{2} \mathrm{O}$ & $\mathrm{MgO}$ & $\mathrm{CaO}$ \\
\hline $\begin{array}{l}\text { Germany (Agricultural } \\
\text { Chamber of Lower Saxony) }\end{array}$ & Varying & ${ }^{1} 160$ & $270-100$ & $80-300$ & 60 & - \\
\hline $\begin{array}{l}\text { Germany (Agricultural } \\
\text { Chamber of North } \\
\text { Rhine-Westphalia) }\end{array}$ & Varying & ${ }^{1} 120-160$ & 2 & $150-300$ & 70 & - \\
\hline $\begin{array}{l}\text { UK (DEFRA recommendation } \\
\text { system })^{3}\end{array}$ & Varying & $40-270$ & $0-250$ & $0-360$ & $0-120$ & - \\
\hline Netherlands & Varying & $0-140^{4}$ & $20-185$ & $0-320(440)$ & $0-200$ & \\
\hline India (North-western hill zone) $)^{5}$ & Acidic hill soil & $120-150$ & $100-150$ & 120 & - & - \\
\hline India (North-eastern hill zone) & Acidic hill soil & $100-120$ & $120-150$ & 60 & - & - \\
\hline $\begin{array}{l}\text { India (North-western, -eastern } \\
\text { and -central plain zone) }\end{array}$ & Alluvial & $180-240$ & $80-100$ & $100-150$ & - & - \\
\hline India (Plateau zone) & Black & $100-120$ & 60 & 60 & - & - \\
\hline India (Nilgiri zone) & Acidic hill & $90-120$ & $135-150$ & 90 & - & - \\
\hline South Africa ${ }^{6}$ & Varying & $110-130^{7}$ & $70-300^{8}$ & $60-340^{9}$ & $0-105^{10}$ & $0-1125$ \\
\hline
\end{tabular}

${ }^{1}$ Desired value, adaptations are needed according to the site-specific fertilisation and crop rotation history and potato variety

2 Based on soil content class ' $C$ '. Soil content classes were established empirically by conducting field trials for a wide range of soil types (explaining the wide range of some recommendations). Content classes are named A-E with A being very low and $\mathrm{E}$ very high. For content class ' $\mathrm{C}$ ', fertilisation at the height of nutrient removal from the field is recommended. Nutrient removal thereby depends on the expected yield level

${ }^{3}$ The wide application ranges are a consequence of including agronomic factors like the length of the growing season ( $<60$ to $>120$ days), the variety and the UK-specific Soil Index system and the Soil Nitrogen Supply (SNS) Index system (taking soil type, rainfall, etc., into account). Values are calculated on a total yield of $50 \mathrm{t} \mathrm{ha}^{-1}$

${ }^{4}$ Calculations based on studies conducted by the University of Wageningen, including $\mathrm{N}_{\text {min }}$, organic fertilisation history and intended use of potato (starch or fresh market potatoes), for $\mathrm{P}$ and $\mathrm{K}$ the waterextractable $\mathrm{P}$, the $\mathrm{HCl}$-extractable $\mathrm{K}$, the $\mathrm{NaCl}$-extractable $\mathrm{Mg}$ and the demand of the crop (potato) is taken into account. In brackets: river and marine clay. $\mathrm{Ca}$ is not mentioned; instead, it is stated that $\mathrm{Ca}$ is typically sufficiently supplied with liming and/or fertilisers together with $\mathrm{N}$ or $\mathrm{P}$

${ }^{5}$ Official recommendation of the Central Potato Research Institute (CPRI), a federal research organisation with a mandate on potato crop research

${ }^{6}$ Fertilisation guidelines according to the Potatoes South Africa and the National Potato Working Groups in South Africa (http://nbsystems.co.za/potato/index_12.htm)

${ }^{7}$ All nutrients are based on the yield potential of $30 \mathrm{t} \mathrm{ha}^{-1}$ and the clay content of the soil and rain-fed production

${ }^{8}$ Based on soil analysis according to Bray 1-2, Olsen and AMBIC 1

${ }^{9}$ Calculations for $\mathrm{K}$ and $\mathrm{Ca}$ based on cation exchange capacity (K, $80 \mathrm{mg} / \mathrm{kg}$; Ca, $750 \mathrm{mg} / \mathrm{kg}$; $\mathrm{Mg}, 121 \mathrm{mg} / \mathrm{kg}$; $\mathrm{Na}, 77 \mathrm{mg} / \mathrm{kg} ; \mathrm{H}, 0.18 \mathrm{me} \%$ ); $\mathrm{H}^{+}$expressed as percentage milli-equivalents (me\%); the fertilisation recommendation range shown here covers cation exchange capacity of me greater and smaller than 6

${ }^{10}$ For $\mathrm{Ca}$ and $\mathrm{Mg}$, no yield potential, but only the soil analysis is taken into account. The values shown here cover the range of soil contents 
Nitrogen $(\mathrm{N})$, phosphorous $(\mathrm{P})$ and potassium $(\mathrm{K})$ are the nutrients which are most commonly fertilised in potato production (Davenport et al. 2005). This might explain why most literature is available for these nutrients with respect to potato production, especially in terms of fertilisation strategies and recommendations. Unfortunately, current literature dealing with fertilisation practices of nutrients other than $\mathrm{N}, \mathrm{P}$ and $\mathrm{K}$ is often lacking (Table 2). This review aims to give an overview on the macronutrients $\mathrm{N}, \mathrm{P}, \mathrm{K}$, magnesium $(\mathrm{Mg})$, calcium $(\mathrm{Ca})$ and sulphur $(\mathrm{S})$ with respect to (1) their most important roles in plant metabolism, (2) their roles for potato yield formation, (3) fertilisation practices (Table 2 ) and recommendations in potato production, if available, and (4) interactions with abiotic factors influencing the plant availability. A critical review of all essential nutrients in potato growth is beyond the scope of this review. Furthermore, important roles of the nutrients in determining potato quality will only briefly be addressed as this review focuses on the importance of plant nutrients for potato yield.

\section{Roles of Macronutrients in Plant Metabolism, Their Role in Potato Yield Formation and Fertilisation Practices}

The nutrients $\mathrm{N}, \mathrm{P}, \mathrm{K}, \mathrm{Mg}, \mathrm{Ca}$ and $\mathrm{S}$ are highlighted successively with respect to their physiological functions in plant metabolism and for tuber yield formation in the following sections of this review. Besides, fertilisation practices will be addressed. Perrenoud (1993) summarised the literature on the uptake of $\mathrm{N}, \mathrm{P}, \mathrm{K}, \mathrm{Mg}$ and $\mathrm{Ca}$ and their removal by potatoes. The mean values are presented in Fig. 1, giving an overview about the need for these nutrients by the potato crop. From the removal per tonne of tubers, the removal (in $\mathrm{kg} \mathrm{ha}^{-1}$ ) was calculated to give a tuber yield of $40 \mathrm{t} \mathrm{ha}^{-1}$.

\section{Nitrogen}

Nitrogen $(\mathrm{N})$ is one of the most crucial macronutrients for plant growth and biomass development. Plants can use $\mathrm{N}$ in different forms. Their major sources are ammonium $\left(\mathrm{NH}_{4}{ }^{+}\right)$and nitrate $\left(\mathrm{NO}_{3}{ }^{-}\right)$(Silva et al. 2013), albeit the latter one is easily prone to leaching. Mandatory roles of $\mathrm{N}$ for plant growth are that it is a component of chlorophyll, amino acids, proteins, nucleic acids, coenzymes and membrane constituents (Andrews et al. 2013; Ahmed et al. 2015). Increasing N supply can increase the proportion of largesized tubers (Zebarth and Rosen 2007). This has a positive effect on potatoes used for processing. However, large-sized tubers might be unfavourable for potatoes used for fresh consumption or for seed production (Zebarth and Rosen 2007). Besides, N can influence several potato quality determinants such as the nitrate (Bélanger et al. 2002) or acrylamide content (Gerendás et al. 2007) of tubers. The second part of this review will discuss these relations between $\mathrm{N}$ and tuber quality in more detail.

$\mathrm{N}$ has the greatest impact on potato yield formation among all essential macronutrients (Bucher and Kossmann 2011; Silva et al. 2013). According to De la Morena et al. (1994), potato yield can be divided into the three components: 'number of stems per square meter', 'number of tubers per stem' and 'average tuber weight', whereby $\mathrm{N}$ has the greatest impact on the average tuber weight. The need for $\mathrm{N}$ of the potato crop is comparatively low within the first 4 to 5 weeks of growth and tuberisation can even be 


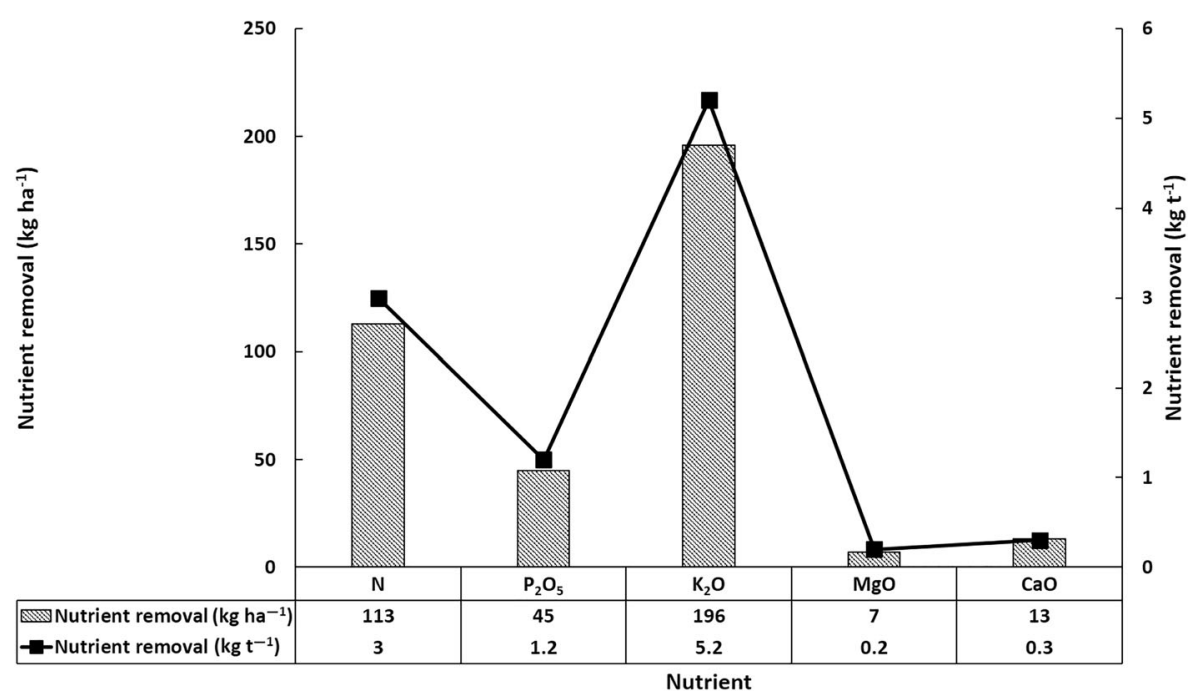

Fig. 1 Removal of $\mathrm{N}, \mathrm{P}_{2} \mathrm{O}_{5}, \mathrm{~K}_{2} \mathrm{O}, \mathrm{MgO}$ and $\mathrm{CaO}$ by potato tubers. Mean values per tonne of tubers (as shown on the right axis), calculated according to Perrenoud (1993) (and literature cited therein). Calculations on nutrient removal per hectare (as shown on the left axis) were based on a $40 \mathrm{t} \mathrm{ha}^{-1}$ tuber yield

suppressed or delayed by high N supply (Jackson 1999; Zebarth and Rosen 2007). During this growth period, nitrogen favours stem growth. This reduces the available amount of dry matter for tubers. However, at a later growth stage, the tubers can take benefit from increased aboveground biomass. Here, $\mathrm{N}$ has a decisive impact on the number of emerging leaves and the rate of leaf expansion, and, therefore, on the canopy development of the plant (Ospina et al. 2014). Hence, it has a positive impact on photosynthesis efficiency by increasing the interception rate of radiation and photons (Vos 1995; Vos and van der Putten 1998; Mauromicale et al. 2006), and, as a consequence, on dry matter partitioning to the tubers, tuber bulking and, finally, on tuber yield formation (Ahmed et al. 2015). The highest amount of $\mathrm{N}$ is needed during tuber bulking. Approximately $58-70 \%$ of the total $\mathrm{N}$ is taken up during this development stage (Ojala et al. 1990). However, with respect to starch concentrations in tubers, it should be noted that increasing $\mathrm{N}$ supply might have a decreasing impact on tuber starch concentrations (\% DW) as has been shown by Sharma and Arora (1988). However, the authors found increasing starch yields $\left(\mathrm{kg} \mathrm{ha}^{-1}\right)$. Sharma and Arora (1988) attributed these findings to a dilution effect in which the increasing yield caused by the $\mathrm{N}$ application affects the starch concentration.

The tuber dry matter yield per unit of applied nitrogen can be defined as nitrogen use efficiency (NUE) (Tiemens-Hulscher et al. 2014). The NUE of potatoes can be regarded as low compared to other crops. This can be attributed to the shallow rooting system of potatoes that leads to a restricted uptake and, thus, use of N (Iwama 2008). However, strong interactions between the NUE and the maturity group of the respective cultivar have been reported. For instance, compared to early maturity types, later maturity types can profit more from additional available $\mathrm{N}$, especially later in the growing season (Tiemens-Hulscher et al. 2014). Moreover, the water regime can have a significant impact on the NUE. Due to the shallow rooting system of potatoes, they are known not only as inefficient in the use of nutrients such as $\mathrm{N}$ but are also very 
sensitive to water shortages (Liu et al. 2015). Thus, potato crops are usually irrigated under dry conditions although excessively high amounts of water can favour nitrogen leaching. As mentioned previously, given their shallow roots, potatoes are often unable to capture $\mathrm{N}$ from deeper soil layers (Cameron et al. 2013). Therefore, the danger of nitrate leaching beyond the rooting zone can increase under excess supply of water (Wolfe et al. 1983). Besides, undesirable $\mathrm{N}$ losses can occur via volatilisation as ammonia $\left(\mathrm{NH}_{3}\right)$ or via denitrification resulting in nitrous oxide $\left(\mathrm{N}_{2} \mathrm{O}\right)$ (Vos 2009), both of which are known as greenhouse gases (Petersen and Sommer 2011).

An appropriate $\mathrm{N}$ supply should be based on calculations that meet the actual plant demand and should include other $\mathrm{N}$ sources; for example, delivered by catch crops or intercrops, like N-fixing leguminous plant species (Bucher and Kossmann 2011; Zebarth et al. 2012; Cameron et al. 2013). Usually, the amount of $\mathrm{N}$ applied to potatoes varies between 100 and $300 \mathrm{~kg} \mathrm{ha}^{-1}$ (Beukema and van der Zaag 1990). There are different methods available for the grower to determine the actual $\mathrm{N}$ demand. These can be distinguished as soil-based or plant-based tests (Zebarth and Rosen 2007). The most commonly used soil-based approach is the soil mineral $\mathrm{N}$ test (Zebarth and Rosen

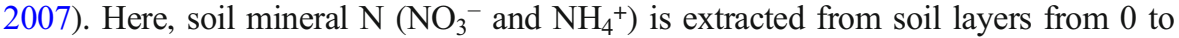
$60 \mathrm{~cm}$ soil depth prior to planting (Vos 2009). Plant-based tests are, for instance, the petiole $\mathrm{N}$ test determining the petiole $\mathrm{NO}_{3}{ }^{-}$concentration (Porter and Sisson 1991) or the use of a leaf chlorophyll meter as indicator for the $\mathrm{N}$ status of the plant (Olivier et al. 2006). Besides, a simple visual diagnosis might be a helpful tool to identify $N$ deficiency during growth. $\mathrm{N}$ deficiency symptoms become visible as leaf chlorosis, due to the disturbance of chloroplasts. Usually, chloroses are equally distributed over the whole leaf. These symptoms occur first on younger leaves as those nutrients cannot be translocated within the plant (Mengel and Kirkby 2001). Nonetheless, meeting the actual $\mathrm{N}$ demand of the crop and making $\mathrm{N}$ fertilisation recommendations remains difficult due to several factors influencing the availability of $\mathrm{N}$ in the soil. These include, for example, the amount of available water or temperature throughout the growing season (Vos 2009).

Many growers supply the total or a large amount of $\mathrm{N}$ fertiliser pre-planting (Ojala et al. 1990). Due to the aforementioned difficulties in meeting actual $\mathrm{N}$ demand of the crop throughout the whole growing season, splitting the $\mathrm{N}$ application has become a commonly used approach (Kelling et al. 2015; Rens et al. 2016a). Splitting the $\mathrm{N}$ application, first, has the potential to lower the risk of nitrogen leaching, especially in irrigated potato production on sandy soils (Errebhi et al. 1998). Second, it can better meet the actual demand of the potato crop with reference to the respective development stage (Ojala et al. 1990). However, splitting the $\mathrm{N}$ application still needs precise management as there are many factors which might affect the efficiency of this process. While excess water availability can favour $\mathrm{N}$ leaching, water shortages can result in reduced solubility of the fertiliser and, thus, in reduced N plant availability (Rens et al. 2016b). Therefore, it cannot be generalised that splitting $\mathrm{N}$ is advantageous in irrigated or non-irrigated production systems. Furthermore, delaying $\mathrm{N}$ supply might delay tuber maturity (Ojala et al. 1990). Therefore, plant development needs to be precisely monitored. Finally, besides the aforementioned $\mathrm{N}$ application practices, foliar application of urea might be an efficient measure to overcome unexpected $\mathrm{N}$ shortages during crop growth (Qadri et al. 2015). 


\section{Phosphorous}

Phosphorous (P) is required in relatively high amounts (Fig. 1) by the potato crop as compared to other crops. $\mathrm{P}$ serves various functions in plant metabolism. Its most prominent role is cellular energy transfer by dephosphorylation of adenosine triphosphate (ATP) to adenosine diphosphate (ADP). Besides this, $\mathrm{P}$ is a structural component of nucleic acids as units in deoxyribonucleic acid and ribonucleic acid molecules, of many coenzymes and of phospholipids in biomembranes (Raghothama 2000; Marschner 2012; Rosen et al. 2014). Economically speaking, P has a significant impact on the setting of potato tubers, especially in the early growth states (Jenkins and Ali 2000; Hopkins et al. 2014), but also at later growth stages where P enhances tuber maturity (Hopkins et al. 2014; Rosen et al. 2014). There are also reports that $\mathrm{P}$ affects tuber size. For instance, a decrease in the yield of large-sized tubers with higher $\mathrm{P}$ fertilisation rates has been observed (Jenkins and Ali 2000). Similarly, there are reports which claim that an increase in small-sized tubers is an offset for the decrease of largesized tubers (Rosen et al. 2014). The potato plant can tolerate moderate P stress without any severe deficiency symptoms until photosynthesis and respiration being reduced to such an extent that carbohydrates accumulate. This becomes obvious in dark green to purple leaf discolorations, as described by Hoppo et al. (1999) and cited in Grant et al. (2001).

Similar to N, the need for $\mathrm{P}$ is rather low in the first weeks of growth but, contrary to $\mathrm{N}, \mathrm{P}$ is also taken up in comparatively large amounts after tuber bulking during the maturity phase of tubers. Most $\mathrm{P}$ is taken up between 40 and 60 days after emergence (Horneck and Rosen 2008; Rosen et al. 2014). There are several P fertiliser management strategies with respect to the rate, placement or timing (Hopkins 2013). With regard to the $\mathrm{P}$ fertiliser rate, soil $\mathrm{P}$ levels should be examined first via soil testing, e.g. with the help of the Mehlich III method (Pote et al. 1996). Usually, lower amounts of fertiliser $\mathrm{P}$ are needed under high soil test $\mathrm{P}$ levels. However, differences have been reported between different soil types: while non-sandy soils, such as loams, still show yield responses at high soil test $\mathrm{P}$ levels, these yield responses were found to be lower in sandy soils (Rosen et al. 2014). With regard to placement, a primary distinction can be made between broadcast and band $\mathrm{P}$ fertiliser application. Due to the shallow root system of potatoes, band application can be advantageous in terms of $\mathrm{P}$ use efficiency as the band is usually placed in close vicinity to the majority of the roots (Hopkins et al. 2014). Moreover, under broadcast application higher $P$ fertiliser rates are often needed: this increases the risk of runoff losses. Therefore, under broadcast application, $\mathrm{P}$ fertiliser should be incorporated into the soil (Rosen et al. 2014). Similar to the application practices for $\mathrm{N}$, there exist also for $\mathrm{P}$ the possibility for an in-season fertiliser application beside pre-planting $\mathrm{P}$ fertiliser application. Although there are several studies which investigate the effect of an in-season $\mathrm{P}$ fertiliser application versus a pre-planting $\mathrm{P}$ fertiliser application, none could be found which showed an increase in $\mathrm{P}$ use efficiency due to splitting of the P application (e.g. Hopkins et al. 2010; Stark and Hopkins 2015). However, P petiole tests during crop growth are still recommended to identify possible P limitations for crop growth (Rosen et al. 2014).

Compared to N, P is very immobile in soils as it is only poorly soluble. Thus, plant roots need to grow in the direction of $\mathrm{P}$ for its uptake. As only a few roots develop during the first growth period, it is a typical time for $\mathrm{P}$ deficiency to occur in potato 
(Hopkins 2013). However, the P use efficiency of potato is rather low even at a later growth stage, similar to that for N (Hopkins 2013). This might, likewise, be attributed to the shallow and inefficient rooting system of potato (Hopkins et al. 2014). Moreover, restricted $\mathrm{P}$ availability can additionally reduce root growth due to its role in cell division (Rosen et al. 2014). Soil pH can have a decisive impact on $\mathrm{P}$ fertiliser solubility. A neutral $\mathrm{pH}$ of 6.0 to 7.5 is assumed to be in the best range in terms of $\mathrm{P}$ solubility. However, $\mathrm{pH}$ values in the acid as well as in the alkaline range can both adversely affect $P$ availability (Hopkins 2013; Rosen et al. 2014). Under acidic soil conditions, $\mathrm{P}$ tends to build poorly soluble mineral precipitates with aluminium, iron or manganese, while under alkaline soil conditions a similar reaction occurs with magnesium or calcium (Hopkins 2013). Due to the high need of potato for $\mathrm{P}$ on the one hand and due to rather low $\mathrm{P}$ use efficiency on the other, $\mathrm{P}$ is often applied in excess amounts (Hopkins et al. 2010). The applied amounts range from 100 to $400 \mathrm{~kg} \mathrm{P} \mathrm{ha}^{-1}$ (Maier et al. 2002; Hopkins et al. 2014). This is a main reason why P, besides N, often contributes to the pollution of surface and groundwater (Davenport et al. 2005) as it directly dissolves into the water or enters the water attached to colloids and particles via soil erosion (Withers and Haygarth 2007). Usually, the water bodies (e.g. lakes) where these $\mathrm{P}$ sources enter are limited in $\mathrm{P}$. Thus, the arrival of $\mathrm{P}$ can result in immense algae blooms leading, finally, to eutrophication of the water body (Withers and Haygarth 2007; Hopkins et al. 2010).

\section{Potassium}

Out of all the macronutrients, potassium $(\mathrm{K})$ has the highest concentrations in potato tubers. It accounts for about $400 \mathrm{mg}$ per $100 \mathrm{~g}$ fresh weight (White et al. 2009) or for about $1.7 \%$ of dry matter (Schilling et al. 2016). It is also the most abundant inorganic cation in the remaining plant tissues, in potato leaves at up to $6 \%$ of dry matter, for instance (Leigh and Wyn Jones 1984; Zorn et al. 2016). These facts are also reflected in the high amounts of $\mathrm{K}$ removal by potatoes (Fig. 1).

The major functions of $\mathrm{K}$ in plants are controlling enzyme activity, cation-anion homeostasis and membrane polarisation. These are based on its osmotic nature, which is why it is needed for cell extension, turgor regulation and stomatal movement (Walker et al. 1996; Liu et al. 2006; Wang and Wu 2013; Adams and Shin 2014; Shabala and Pottosin 2014). One important role of $\mathrm{K}$ for the potato crop's enzyme functions is stimulating the starch synthase for starch synthesis (Hawker et al. 1979). A sufficient supply of $\mathrm{K}$ is also needed for high biomass production and leaf area development. Under $\mathrm{K}$ deficiency, there can be a decrease in the number of leaves as well as a decrease in the leaf size. This can be attributed to K's role in osmoregulation and cell extension (Gerardeaux et al. 2010; Jákli et al. 2016). Besides the aforementioned functions, $\mathrm{K}$ is crucial for photosynthesis and the distribution of photosynthates via the phloem. To maintain a proper working photosynthesis, an accurate working stomatal movement is needed to take up considerable amounts of $\mathrm{CO}_{2}$ for fixation in the Calvin cycle (Cakmak 2005; Zörb et al. 2014). Koch et al. (2019a) could demonstrate in pot experiments with potato plants that K-deficient plants exhibit a significantly reduced $\mathrm{CO}_{2}$ net assimilation rate. Moreover, the processes involved in photosynthesis require a fine-tuned $\mathrm{pH}$ regulation because photosynthetic enzymes need a specific pH to function efficiently (Rumberg and Siggel 1969; Woodrow and Berry 
1988). For instance, this is true for ribulose-1,5-bisphosphate (RuBP) carboxylase as a key enzyme involved in photosynthetic carbon fixation. However, the maintenance of photosynthesis is also dependent on the export of photosynthates from source to sink organs. Under K deficiency, there can be an accumulation of sucrose in leaves, which has been found in potato plants (Koch et al. 2019a). The accumulation of sucrose in the leaves of K-deficient plants occurs due to impaired phloem loading and transport of sucrose in phloem. $\mathrm{K}$ is also needed for stabilising a specified $\mathrm{pH}$ value for energyproviding ATP production for phloem loading, whereas for distribution of sucrose within the phloem, K establishes the needed osmotic pressure (Cakmak et al. 1994a). Based on the aforementioned roles of $\mathrm{K}$ in enzyme regulation, photosynthesis and partitioning of carbohydrates within the plant, it can be assumed that $\mathrm{K}$ has a central relevance in the potato crop for establishing desired tuber and starch yields. Indeed, Koch et al. (2019a) could show that K-deficient potato plants exhibited significant tuber yield and starch yield (g starch plant ${ }^{-1}$ ) reductions. However, the starch concentrations (\% in DW) did not show significant reductions upon $\mathrm{K}$ deficiency. With respect to other potato quality determinants, $\mathrm{K}$ is a nutrient with several important functions. Besides dry matter, starch content and specific gravity, $\mathrm{K}$ can affect the content of reducing sugars, which are precursors for acrylamide formation in processed potato products (Panique et al. 1997; Gerendás et al. 2007). Furthermore, K can lower black spot bruise (McNabnay et al. 1999) and after-cooking darkening (Wang-Pruski and Nowak 2004) due to an increase in organic acids upon K application. For more on the roles of $\mathrm{K}$ in determining potato quality, please refer to the second part of this review.

The potato plant shows maximum uptake of $\mathrm{K}$, similar to $\mathrm{N}$, early in plant development, approximately 30 to 40 days after emergence (Stark et al. 2004; Horneck and Rosen 2008). The previously described roles of $\mathrm{K}$ for leaf area development and photosynthesis might be a reason for this. Besides, $\mathrm{K}$ has a decisive role in tuber initiation and tuber bulking (Karam et al. 2009). Afterwards, similar to N, the uptake of $\mathrm{K}$ drops close to zero during the maturity phase of the tubers (Stark et al. 2004; Horneck and Rosen 2008).

Corresponding to high amounts of $\mathrm{K}$ removal and $\mathrm{K}$ concentrations of tubers, recommendations for $\mathrm{K}$ fertilisation are usually quite high (Panique et al. 1997). However, there are several studies which could not find a positive effect of $\mathrm{K}$ fertilisation on tuber yield (Roberts and Beaton 1988; Kang et al. 2014; Koch et al. $2019 b$ ). This might be attributed to an already sufficient K status of the respective soils. Tuber yield seems to reach a maximum at a certain available $\mathrm{K}$ level, but as has been demonstrated by Kang et al. (2014), an additional supply seems not to have any further effect. Nevertheless, there are indications that the potato crop is able to take up more K than is actually required (Kang et al. 2014). However, especially in sandy soils, the danger of loss of $\mathrm{K}$ due to leaching is high because $\mathrm{K}$ is very mobile in the soil (Wulff et al. 1998). Thus, applications of $\mathrm{K}$ higher than the actual demand are not recommended and $\mathrm{K}$ fertilisation decisions should be based on soil $\mathrm{K}$ tests. Panique et al. (1997) suggest that soil $\mathrm{K}$ values below $104 \mathrm{mg} \mathrm{K} \mathrm{kg}^{-1}$ for sandy soils and below the range of 100 to $125 \mathrm{mg} \mathrm{K} \mathrm{kg}^{-1}$ for medium-textured soils, such as silty loams, are critical. $\mathrm{K}$ deficiency occurring during crop growth might be identified by petiole testing (Stark et al. 2004) or with help of visual analysis. When $\mathrm{K}$ is depleted in the potato plant, leaves start to develop chlorosis, even on leaf edges or in the form of dots 
(Zorn et al. 2016). As $\mathrm{K}$ is phloem-mobile, the symptoms of $\mathrm{K}$ deficiency occur first on older leaves because $\mathrm{K}$ will be translocated from older to younger developing leaves. In addition, an increased root-to-shoot ratio can be observed (Cakmak et al. 1994a; Cakmak et al. 1994b).

Usually, all the $\mathrm{K}$ is applied pre-planting (Stark et al. 2004; Horneck and Rosen 2008). In-season split applications have been shown to have no increasing effect on tuber yield (Westermann and Tindall 1995; Kumar et al. 2007). Stark et al. (2004) recommend a broadcast $\mathrm{K}$ application at the pre-planting stage as band application might lead to salt stress.

The form of $\mathrm{K}$ application, for example as sulphate or chloride, can have tremendous effects on assimilate distribution and, therefore, on yield formation and other important quality aspects of potato. In general, independent of the $\mathrm{K}$ source that is supplied (either as $\mathrm{K}_{2} \mathrm{SO}_{4}$ or $\mathrm{KCl}$ ), the yield can be increased by increasing $\mathrm{K}$ fertilisation (Panique et al. 1997). However, it is assumed that, compared to the sulphate form, fertilisation of $\mathrm{K}$ in chloride form leads to higher osmotic potential in the crops as osmotically active chloride is accumulated in higher amounts than sulphate. This leads to higher water uptake and, therefore, higher vegetative growth. Higher vegetative growth rates, particularly of the above-ground plant parts, lead to increased competition for assimilates between shoot and tuber, as the shoot is a strong sink for such assimilates. In addition, chloride-induced high growth rates of the shoot as a result of increased water uptake lead to dilution of $\mathrm{K}$ (and other nutrients) in the plant. As $\mathrm{K}$ is important for phloem loading and distribution processes in plants, such reduced $\mathrm{K}$ concentrations in the plant matter could impair assimilate translocation to the roots and, therefore, to the tubers (Beringer et al. 1990). However, recently, Hütsch et al. (2018) could demonstrate in pot experiments with the two cultivars Marabel and Désirée that both cultivars were not chloride sensitive and did not show any tuber yield or quality reductions. Thus, the authors argue, potatoes are not necessarily chloride sensitive, although it needs to be noted that both the cultivars used, Marabel and Désirée, are potatoes for fresh consumption (FPVO 2018), i.e. these tubers are usually characterised by lower starch contents as compared to cultivars for chips, fries or starch production. Kumar et al. (2007) investigated the impact of $\mathrm{K}_{2} \mathrm{SO}_{4}$ versus $\mathrm{KCl}$ on dry matter percentage and crispiness of two processing cultivars and found them to be superior when they received $\mathrm{K}$ as $\mathrm{K}_{2} \mathrm{SO}_{4}$ instead of $\mathrm{KCl}$. Moreover, Marabel belongs to the early maturity group and Désirée to the medium-early maturity group (FPVO 2018). The usage type and maturity group might both have tremendous effect on the amount of assimilates needed for translocation to the tubers. Therefore, it is feasible that different cultivars and maturity groups respond differently in terms of chlorine sensitivity.

\section{Magnesium}

Magnesium ( $\mathrm{Mg}$ ) can be designated as 'the forgotten element in crop production' (Cakmak and Yazici 2010) as its supply and the need for it are usually underestimated. But due to its several key roles, especially in photosynthesis, the partitioning of photoassimilates, protein synthesis and enzyme regulation, $\mathrm{Mg}$ deficiency can lead to impaired growth and yield formation (Cakmak and Yazici 2010; Senbayram et al. 2015). Along with $\mathrm{K}, \mathrm{Mg}$ serves as a cation in similar physiological processes, for example, in the regulation of the cation-anion balance and as an osmotically active ion 
in the turgor regulation of cells (Marschner 2012). In addition, Mg contributes, like K, to maintain a stable $\mathrm{pH}$ for proper activity of photosynthetic enzymes, for example, for RuBP (Woodrow and Berry 1988; Yuguan et al. 2009). Moreover, Mg specifically binds to RuBP and thereby enhances its catalytical activity (Belknap and Portis 1986). Besides RuBP, Mg is an allosteric activator of more than 300 enzymes (Verbruggen and Hermans 2013; Senbayram et al. 2015). The most commonly known function of $\mathrm{Mg}$ in photosynthesis is its role as a central atom of the chlorophyll molecule, the organic molecule capable of scavenging sunlight and transforming it into electron transport and, hence, chemical energy (Walker and Weinstein 1994; Verbruggen and Hermans 2013). In protein synthesis, $\mathrm{Mg}$ is vital for bridging two subunits of ribosomes, the location of the translation of proteins, to their active form (Sperrazza and Spremulli 1983). One more essential role that $\mathrm{Mg}$ shares with $\mathrm{K}$ is located in the partitioning of carbohydrates. $\mathrm{Mg}$ is required for phloem loading with sucrose as it is an allosteric activator of ATPases, which create a proton gradient that provides energy for the transport of sucrose and protons via sucrose $/ \mathrm{H}^{+}$symporters (Hermans et al. 2005). As pointed out, $\mathrm{Mg}$ serves like $\mathrm{K}$ in crucial functions for photosynthesis and carbohydrate partitioning. Although Koch et al. (2019a) could not find any reduction in the $\mathrm{CO}_{2}$ net assimilation rate in $\mathrm{Mg}$-deficient potato plants, $\mathrm{Mg}$-deficient plants revealed significant accumulations of soluble sugars in source leaves, indicating a restricted phloem-loading process in these plants. Moreover, the authors could determine significant tuber yield and starch yield (g starch plant ${ }^{-1}$ ) reductions. However, as described for $\mathrm{K}$, the starch concentrations (\% in DW) did not differ between $\mathrm{Mg}$ deficient and sufficient supplied plants.

Cakmak et al. (1994a) and Ceylan et al. (2016) reported as a consequence of impaired phloem loading that plants which were deficient in $\mathrm{Mg}$ (and also $\mathrm{K}$ ) accumulated sucrose in their leaves, whereas, simultaneously, the concentration of sucrose in the phloem sap decreased. Evidence was also provided that a re-supply of $\mathrm{Mg}$ to $\mathrm{Mg}$ deficient plants for only 1 day was very effective in restoring the phloem transport of sucrose (Cakmak and Kirkby 2008). This rapid correction of the phloem transport system following a re-supply of $\mathrm{Mg}$ indicates that foliar applications of soluble $\mathrm{Mg}$ fertilisers in field crops can provide a fast and effective remedial treatment for $\mathrm{Mg}$ deficiency.

Furthermore, there is evidence that $\mathrm{Mg}$ has an impact on root growth and morphology, but with contradictory results. Cakmak et al. (1994a, 1994b) showed a decrease in dry matter production in the roots compared to the shoots of bean plants grown in a nutrient solution under conditions of $\mathrm{Mg}$ deficiency, while Hermans et al. (2005) documented almost no effect on root biomass development after transferring sugar beet plants into an Mg-depleted nutrient solution. This might be explained by the fact that both authors used different approaches: Cakmak et al. (1994a, 1994b) induced $\mathrm{Mg}$ deficiency at germination or at a very early growth stage, while Hermans et al. (2005) grew their plants first under conditions of sufficient Mg supply before transferring them into an $\mathrm{Mg}$-depleted nutrient solution. It seems as if plants are able to overcome $\mathrm{Mg}$ depletion in the later growth stages without any severe impact on root growth or morphology when they had earlier been sufficiently supplied with $\mathrm{Mg}$. In a more recent study, following the approach by Cakmak et al. (1994a, 1994b) to induce $\mathrm{Mg}$ deficiency at a very early growth stage, Koch et al. (2019a) found significant root biomass and total root length reductions upon $\mathrm{Mg}$ deficiency in potato plants. It is 
likely that impaired root growth is a result of hampered assimilate translocation processes (Cakmak et al. 1994a, 1994b; Koch et al. 2019a). Moreover, depending on growth conditions, plants having deficiency of $\mathrm{Mg}$ might develop an increased root-toshoot ratio (Cakmak et al. 1994a, 1994b).

The symptoms of $\mathrm{Mg}$ deficiency, such as interveinal chlorosis, and $\mathrm{K}$ deficiency can be first observed in older leaves, as $\mathrm{Mg}$ can easily be translocated to active growing plant parts (Cakmak and Kirkby 2008; White and Broadley 2009; Gransee and Führs 2013).

Recommendations for the fertilisation of $\mathrm{Mg}$ are hard to find in literature. In practice, the applied amounts of $\mathrm{K}$ usually determine the respective $\mathrm{Mg}$ supply. Thereby, the amounts of $\mathrm{K}$ and $\mathrm{Mg}$ are applied in a ratio of 3:1. Koch et al. (2019a) investigated the impact of different amounts of $\mathrm{K}$ and $\mathrm{Mg}$ applications on potato yield and further parameters and found that there is no yield improvement by increasing the $\mathrm{K}$ amount in this ratio but a decrease in the concentrations of $\mathrm{Mg}$ in leaves. Besides, lowering the $\mathrm{K}$ or $\mathrm{Mg}$ supply resulted in significant yield decreases. Thus, the authors could demonstrate that an $\mathrm{Mg}$ application, based on a ratio of $\mathrm{K}$ to $\mathrm{Mg}$ of $3: 1$, is a recommendable fertilisation strategy for $\mathrm{Mg}$.

\section{Potassium-Magnesium Antagonisms}

The competition of cations for uptake is a well-known phenomenon (Fageria 2001). One of the most commonly observed phenomena based on cation antagonism is Kinduced Mg deficiency. Indeed, Koch et al. (2019a) could find a significant decrease in $\mathrm{Mg}$ leaf concentrations with higher $\mathrm{K}$ supply in potato plants. Besides, the highest $\mathrm{Mg}$ leaf concentrations were determined in plants receiving the lowest $\mathrm{K}$ supply (Koch et al. 2019a). These alleged interactions between both nutrients could be the effect of the specificity of $\mathrm{K}$ transporters on the one hand and the unspecificity of $\mathrm{Mg}$ transporters on the other hand involved in $\mathrm{K}$ and $\mathrm{Mg}$ uptake from the soil solution. The delivery of $\mathrm{K}$ and $\mathrm{Mg}$ to the roots follows typically different mechanisms: while $\mathrm{Mg}$ is mainly delivered by mass flow and, to a smaller extent, by interception, $\mathrm{K}$ is mainly delivered by diffusion (Strebel and Duynisveld 1989; Barber 1995; Marschner 2012). To ensure delivery to the roots, plants need to decrease $\mathrm{K}$ concentration in the soil solution of the rhizosphere in order to drive K flux to the roots via diffusion. In contrast, $\mathrm{Mg}$ is present in the soil solution in much higher concentrations. Hence, delivery to the plant roots is mainly enabled by mass flow (Zhang and George 2002). It may so happen that the delivery by mass flow is higher than the uptake by plants, which would result in the accumulation of $\mathrm{Mg}$ in the rhizosphere (Zhang and George 2002). In addition, Mg adsorbs less to the soil matrix due to its high hydrated radius and, therefore, can be leached out. As compared to $\mathrm{K}$, this reduces the availability of $\mathrm{Mg}$ to the roots (Deng et al. 2006). However, the main reason leading to different uptake rates of $\mathrm{K}$ and $\mathrm{Mg}$ may be due to the unspecificity of $\mathrm{Mg}$ transporters, which also take up, beside $\mathrm{Mg}$, other cations like K. Therefore, Mg uptake can be blocked under high plant-available K concentrations in the soil solution even though $\mathrm{K}$ uptake can be facilitated by $\mathrm{Mg}$ transporters (Gransee and Führs 2013). At the same time, there are very specific K transporters which ensure, depending on the $\mathrm{K}$ concentration in the soil solution, $\mathrm{K}$ uptake at low (HATS = High Affinity Transport System) as well as at high K concentrations $($ LATS $=$ Low Affinity Transport System) (Britto and Kronzucker 2008). 
However, these specific K transporters do not transport Mg (Gransee and Führs 2013). Hence, while the uptake of $\mathrm{K}$ is ensured, even under low $\mathrm{K}$ concentrations, due to uptake by specific $\mathrm{K}$ transport systems as well as by unspecific $\mathrm{Mg}$ transporters, $\mathrm{Mg}$ uptake can be impaired even if there is enough $\mathrm{Mg}$ available in the soil solution due to the unspecificity of $\mathrm{Mg}$ transporters as well as of $\mathrm{K}$ transporters for $\mathrm{Mg}$.

With reference to the described antagonistic effects, it is often wrongly concluded that $\mathrm{K}$ and $\mathrm{Mg}$ should not be applied together in order to prevent antagonistic effects during uptake. As can be seen in Fig. 2, the yield of the control treatment receiving $\mathrm{Mg}$ in the form of $400 \mathrm{~kg} \mathrm{ha}^{-1}$ as magnesium sulphate (ESTA® Kieserit), but no K, was higher than the yield of the plants that received the highest amount of $\mathrm{K}$ in the form of $300 \mathrm{~kg} \mathrm{~K}_{2} \mathrm{O}$ as $\mathrm{K}_{2} \mathrm{SO}_{4} \mathrm{ha}^{-1}$ but no $\mathrm{Mg}$. Moreover, in view of comparably low soil $\mathrm{Mg}$ status, the high $\mathrm{K}$ supply further reduced $\mathrm{Mg}$ uptake by the potato plants. Hence, at least a slight $\mathrm{Mg}$ deficiency in single $\mathrm{K}$ treatment could be expected, finally leading to reduced yield. Only the combination of $\mathrm{K}$ and $\mathrm{Mg}$ supply revealed the highest yield.

\section{Calcium}

Calcium $(\mathrm{Ca})$ is essential for the potato crop, mainly due to its role in cell wall and membrane stabilisation (Kirkby and Pilbeam 1984; White and Broadley 2003), its function as a counter-cation for inorganic and organic anions in the vacuole (White and Broadley 2003; Marschner 2012) and as a second messenger in intracellular signal transduction processes (Pottosin and Schonknecht 2007). Ca has extremely low cytosolic concentrations of less than $1 \mu \mathrm{M}$. A major part of $\mathrm{Ca}$ is present in bound form. However, the most water-soluble $\mathrm{Ca}$ is stored in vacuoles (Pottosin and Schonknecht 2007), where it contributes to the anion-cation balance (White and Broadley 2003;

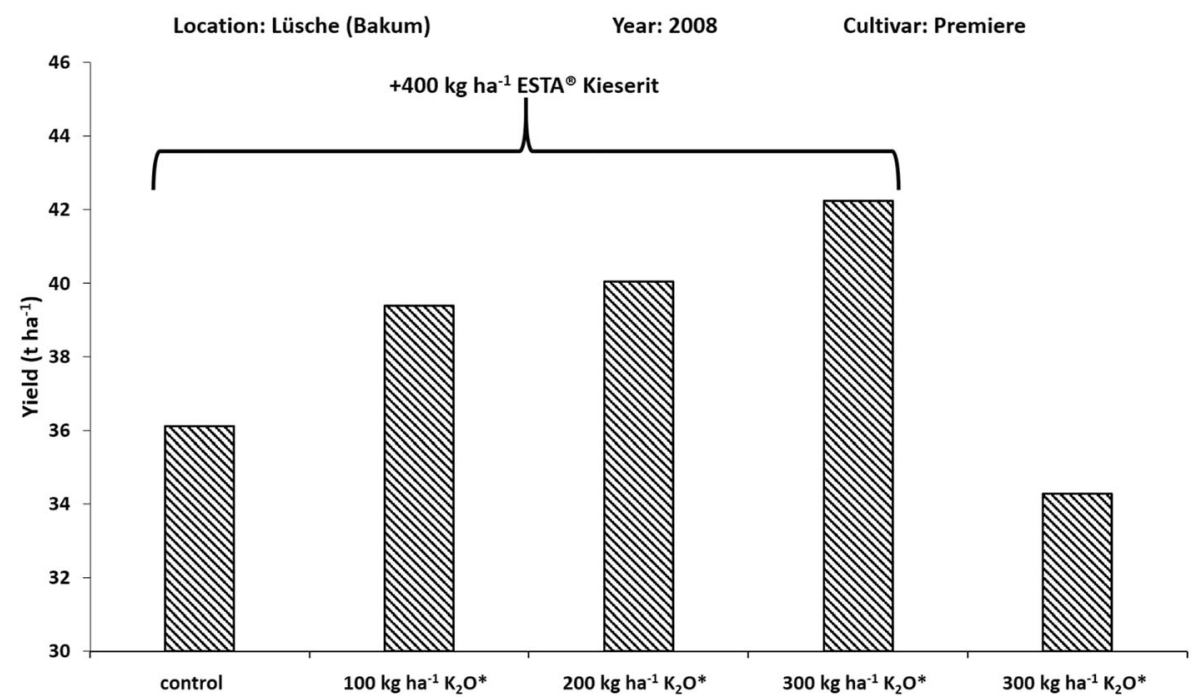

Fig. 2 Effect of combined $\mathrm{K}$ and $\mathrm{Mg}$ fertilisation on yield of potato. The experimental site was Lüsche (Bakum), Northwest Germany, predominantly characterised by silty sand. Soil analysis showed $13.6 \mathrm{mg} \mathrm{K}_{2} \mathrm{O} 100 \mathrm{~g}^{-1}$ soil after calcium acetate lactate (CAL) extraction and $3.2 \mathrm{mg} \mathrm{Mg} / 100 \mathrm{~g}^{-1}$ soil after $\mathrm{CaCl}_{2}$ extraction; ESTA® Kieserit $=25 \% \mathrm{MgO}$ (water soluble) and $50 \% \quad \mathrm{SO}_{3}$ (water soluble); *As KALISOP® gran. $=50 \% \mathrm{~K}_{2} \mathrm{O}$ (water-soluble) and $45 \% \mathrm{SO}_{3}$ (water soluble) 
Marschner 2012). The resulting huge concentration differences between cytosol and vacuole form the basis for Ca's role as a second messenger (Pottosin and Schonknecht 2007). Ca enables the plant to communicate information about the environment at the plant cell level (Whalley and Knight 2013). This forwarding of information can be triggered by different abiotic and biotic stimuli of the surrounding outside environment, like drought or oxidative stress as well as pathogens (McAinsh and Pittman 2009).

The most abundant polysaccharide of primary cell walls is pectin (Jarvis 1984). Due to its divalent nature, $\mathrm{Ca}$ is able to form a bridge between the galacturonates of pectin via carboxylate groups, thus contributing to the characteristic structure of cell walls (Subramanian et al. 2011). Besides structural function in cell walls, Ca is fundamental for the stability of membranes. Here, it bridges the phosphate and carboxylate groups of phospholipids and proteins at membrane surfaces (Legge et al. 1982; Kirkby and Pilbeam 1984).

Ca moves within the plant via the xylem; therefore, Ca transport strongly depends on the transpiration of the plant (White and Broadley 2003; Subramanian et al. 2011). There are studies available that indicated $\mathrm{Ca}$ concentrations also in phloem sap but without further transport (Clarkson 1984). Clarkson (1984) argues that these observations, together with the fact that $\mathrm{Ca}$ easily interacts with macromolecules, means transport must occur along extracellular pathways together with water. In addition, $\mathrm{Ca}$ cannot be translocated from older to younger leaves, as $\mathrm{Ca}$ is not mobile within the phloem and young leaves usually have a low transpiration rate. Consequently, deficiency symptoms regularly occur first in young leaves (White and Broadley 2003). Potato tubers have very low $\mathrm{Ca}$ concentrations, which can also be attributed to $\mathrm{Ca}$ transport mainly occurring via the xylem and the fact that tubers hardly transpire. The most $\mathrm{Ca}$ is distributed in the above-ground parts of the plant (Ozgen et al. 2006; Kärenlampi and White 2009). Kratzke and Palta (1985) demonstrated that Ca uptake and subsequent transport within the potato plant needs to be distinguished between different root types. First, there are the main roots, transporting water mainly to the aboveground parts of the plant. Second, there are the stolon roots arising from the stolons and the tuber roots arising directly from the base of the buds on the tuber. These latter root types could be shown to transport water mainly to the tubers (Kratzke and Palta 1985). As Ca and water are usually transported together, a follow-up study was conducted: it was demonstrated that a $\mathrm{Ca}$ application in the area surrounding tubers and stolons could cause a threefold increase of the Ca concentrations in tubers (Palta 2010). Thus, stolon and tuber roots may have a decisive role in the supply of $\mathrm{Ca}$ to the tubers.

The potato crop is known to tolerate low soil $\mathrm{pH}$ values and is often grown under very acidic soil conditions, for example at $\mathrm{pH}$ values of 4.6 (van Lierop et al. 1982; Lazarević et al. 2014). Although liming can usually increase potato yields, people often refrain from liming these soils as soils with higher $\mathrm{pH}$ values could favour the development of common scab (Streptomyces spp.) (van Lierop et al. 1982; Waterer 2002). However, other severe problems related to low soil $\mathrm{pH}$ conditions may arise: these make it difficult to determine a recommendation for an ideal $\mathrm{pH}$ value for growing potatoes. The acidification of soils is frequently associated with deficiency of essential plant cations like $\mathrm{Ca}$ and $\mathrm{Mg}$ due to an antagonistic and inhibited uptake of these cations by metals like aluminium $(\mathrm{Al})$ and manganese $(\mathrm{Mn})$. Moreover, $\mathrm{Al}$ and Mn can cause toxic reactions in the plant. Therefore, under acidic soil conditions, liming with materials such as $\mathrm{CaCO}_{3}, \mathrm{CaO}$ and $\mathrm{Ca}(\mathrm{OH})_{2}$ can not only improve the 
supply of $\mathrm{Ca}$ but also neutralise the soil $\mathrm{pH}$ and reduce the risk of $\mathrm{Al}$ or $\mathrm{Mn}$ toxicity in the plant (Mengel and Kirkby 2001; Lazarević et al. 2014). On the other hand, when $\mathrm{pH}$ is raised, it is possible that essential plant nutrients like phosphorous and zinc can be less available to plants (Haynes 1990).

\section{Sulphur}

Sulphur (S) is essential for many cellular metabolites and, therefore, can be a nutrient that limits plant yield and quality (Koprivova and Kopriva 2016). For instance, S is a component of amino acids like methionine and cysteine, which are essential building blocks of proteins (De Kok et al. 2005; Galili and Amir 2013). Eppendorfer and Eggum (1994) found severe reductions of these amino acids in potatoes suffering S deficiency. Sharma et al. (2011) found increase in dry matter, specific gravity and starch content with increase in $\mathrm{S}$ supply. However, the authors determined the highest values with an $\mathrm{S}$ supply of $45 \mathrm{~kg} \mathrm{ha}^{-1}$. S levels above $45 \mathrm{~kg} \mathrm{ha}^{-1}$ did not show any further effect on the investigated parameters. Compared to other crops, like the Brassica species, potato has a comparatively low demand for S (Barczak and Nowak 2015), but several highyielding years might remove considerable amounts of $\mathrm{S}$ from the soil. S fertilisation has been shown to increase the resistance of potato against Streptomyces scabies, which is probably caused by a decrease of soil $\mathrm{pH}$ due to $\mathrm{S}$ supply (Klikocka et al. 2005). Moreover, S supply could cause a reduction in the infection rate with Rhizoctonia solani (Klikocka et al. 2005).

Plants with S deficiency develop a yellowish phenotype similar to conditions caused by $\mathrm{N}$ deficiency. Both are based on a loss of chlorophyll. Although under S deficiency there is no direct impact on chlorophyll, S deficiency inhibits the synthesis of thylakoid membranes and, therefore, promotes chlorophyll deficiency (Imsande 1998). S can be translocated within the plant both via phloem and xylem, although translocation via the phloem from older to younger leaves can be restricted. This is why deficiency symptoms (as yellowing similar $\mathrm{N}$ deficiency) often occur first in younger leaves (Mengel and Kirkby 2001). However, as potatoes are usually fertilised with $\mathrm{K}_{2} \mathrm{SO}_{4}$ instead of $\mathrm{KCl}$, it can be expected that the need of potatoes for $\mathrm{S}$ should usually be covered via an application of $\mathrm{K}_{2} \mathrm{SO}_{4}$.

Although atmospheric $\mathrm{S}$ can be absorbed by higher plants in the form of $\mathrm{SO}_{2}$, the highest amount of $\mathrm{S}$ is absorbed by the roots (De Kok et al. 2005). Atmospheric $\mathrm{S}$ concentrations strongly depend on anthropogenic $\mathrm{SO}_{2}$ emissions and vary among continents and regions (Smith et al. 2011). While there has been a decrease in emissions by up to $50 \%$ in the last few years in USA, Canada and Central and Western Europe, there has been a two- or threefold increase in emissions in Africa, China, Australia and New Zealand.

\section{Conclusion}

Beside other agronomic strategies, adequate supply of nutrients is of main importance for achieving desired potato yield. In order to find the optimal level of nutrient supply, it is, as a first step, important to understand individual physiological functions of each nutrient. Moreover, resulting features such as nutrient antagonism or site-specific 
effects providing varying abiotic and biotic environmental conditions need to be taken into account as well. Based on this fundamental knowledge, a potato grower may decide the accurate choice of type, time and amount of fertiliser application.

Open Access This article is distributed under the terms of the Creative Commons Attribution 4.0 International License (http://creativecommons.org/licenses/by/4.0/), which permits unrestricted use, distribution, and reproduction in any medium, provided you give appropriate credit to the original author(s) and the source, provide a link to the Creative Commons license, and indicate if changes were made.

\section{References}

Adams E, Shin R (2014) Transport, signaling, and homeostasis of potassium and sodium in plants. J Integr Plant Biol 56:231-249. https://doi.org/10.1111/jipb.12159

Ahmed A, Zaki M, Shafeek M, Helmy Y, El-Baky MA (2015) Integrated use of farmyard manure and inorganic nitrogen fertilizer on growth, yield and quality of potato (Solanum tuberosum L.). Int J Curr Microbiol App Sci 4:325-349

Andre CM, Legay S, Iammarino C, Ziebel J, Guignard C, Larondelle Y, Hausman J-F, Evers D, Miranda LM (2014) The potato in the human diet: a complex matrix with potential health benefits. Potato Res 57:201214. https://doi.org/10.1007/s11540-015-9287-3

Andrews M, Raven JA, Lea PJ (2013) Do plants need nitrate? The mechanisms by which nitrogen form affects plants. Ann Appl Biol 163:174-199. https://doi.org/10.1111/aab.12045

Bahl A, Kahl G (1995) Air pollutant stress changes the steady-state transcript levels of three photosynthesis genes. Environ Pollut 88:57-65. https://doi.org/10.1016/0269-7491(95)91048-P

Barber SA (1995) Soil nutrient bioavailability: a mechanistic approach. John Wiley \& Sons, Purdue

Barczak B, Nowak K (2015) Effect of sulphur fertilisation on the content of macroelements and their ionic ratios in potato tubers. J Elem 20:37-47. https://doi.org/10.5601/jelem.2014.19.1.471

Bélanger G, Walsh JR, Richards JE, Milburn PH, Ziadi N (2002) Nitrogen fertilization and irrigation affects tuber characteristics of two potato cultivars. Am J Potato Res 79:269-279. https://doi.org/10.1007 /BF02986360

Belknap WR, Portis AR (1986) Activation and carbon dioxide exchange kinetics of ribulose-1,5-bisphosphate carboxylase/oxygenase: negative cooperativity with respect to magnesium. Biochemistry 25:1864-1869. https://doi.org/10.1021/bi00356a004

Beringer H, Koch K, Lindhauer MG (1990) Source: sink relationships in potato (Solanum tuberosum) as influenced by potassium chloride or potassium sulphate nutrition. In: van Beusichem ML (ed) Plant nutrition - physiology and applications. Springer, Dordrecht, pp 639-642. https://doi.org/10.1007/97894-009-0585-6_107

Beukema H, van der Zaag DE (1990) Introduction to potato production. Pudoc, Wageningen

Britto DT, Kronzucker HJ (2008) Cellular mechanisms of potassium transport in plants. Physiol Plant 133: 637-650. https://doi.org/10.1111/j.1399-3054.2008.01067.x

Bucher M, Kossmann J (2011) Molecular physiology of the mineral nutrition of the potato. In: Vreugdenhil D (ed) Potato biology and biotechnology: advances and perspectives. Elsevier, Amsterdam, pp 311-330

Cakmak I (2005) The role of potassium in alleviating detrimental effects of abiotic stresses in plants. J Plant Nutr Soil Sci 168:521-530. https://doi.org/10.1002/jpln.200420485

Cakmak I, Kirkby EA (2008) Role of magnesium in carbon partitioning and alleviating photooxidative damage. Physiol Plant 133:692-704. https://doi.org/10.1111/j.1399-3054.2007.01042.x

Cakmak I, Yazici AM (2010) Magnesium: a forgotten element in crop production. Better Crops 94:23-25

Cakmak I, Hengeler C, Marschner H (1994a) Changes in phloem export of sucrose in leaves in response to phosphorus, potassium and magnesium-deficiency in bean-plants. J Exp Bot 45:1251-1257. https://doi. org/10.1093/jxb/45.9.1251

Cakmak I, Hengeler C, Marschner H (1994b) Partitioning of shoot and root dry-matter and carbohydrates in bean-plants suffering from phosphorus, potassium and magnesium-deficiency. J Exp Bot 45:1245-1250. https://doi.org/10.1093/jxb/45.9.1245

Cameron KC, Di HJ, Moir JL (2013) Nitrogen losses from the soil/plant system: a review. Ann Appl Biol 162: 145-173. https://doi.org/10.1111/aab.12014 
Ceylan Y, Kutman UB, Mengutay M, Cakmak I (2016) Magnesium applications to growth medium and foliage affect the starch distribution, increase the grain size and improve the seed germination in wheat. Plant Soil 406:145-156. https://doi.org/10.1007/s11104-016-2871-8

Clarkson DT (1984) Calcium transport between tissues and its distribution in the plant. Plant Cell Environ 7: 449-456. https://doi.org/10.1111/j.1365-3040.1984.tb01435.x

Davenport JR, Milburn PH, Rosen CJ, Thornton RE (2005) Environmental impacts of potato nutrient management. Am J Potato Res 82:321-328. https://doi.org/10.1007/BF02871962

De Kok LJ, Castro A, Koralewska A, Durenkamp M, Posthumus FS, Stuiver C, Yang L, Stulen I (2005) Pathways of plant sulfur uptake and metabolism: an overview. Landbauforschung Völkenrode 283:5-13

De la Morena I, Guillén A, del Moral LFG (1994) Yield development in potatoes as influenced by cultivar and the timing and level of nitrogen fertilization. Am Potato J 71:165-173. https://doi.org/10.1007 /BF02849051

De Wit CT (1992) Resource use efficiency in agriculture. Agric Syst 40:125-151. https://doi.org/10.1016 /0308-521X(92)90018-J

De Wit CT (1994) Resource use analysis in agriculture: a struggle for interdisciplinarity. In: Fresco LO, Stroosnijder L, Bouma J, van Keulen H (eds) The future of the land: mobilising and integrating knowledge for land use options. John Wiley \& Sons, Wageningen, pp 41-55

Deng W, Luo K, Li D, Zheng X, Wei X, Smith W, Thammina C, Lu L, Li Y, Pei Y (2006) Overexpression of an Arabidopsis magnesium transport gene, AtMGT1, in Nicotiana benthamiana confers Al tolerance. J Exp Bot 57:4235-4243. https://doi.org/10.1093/jxb/erl201

Drewnowski A, Rehm CD (2013) Vegetable cost metrics show that potatoes and beans provide most nutrients per penny. PLoS One 8:e63277. https://doi.org/10.1371/journal.pone.0063277

Ekin Z (2011) Some analytical quality characteristics for evaluating the utilization and consumption of potato (Solanum tuberosum L.) tubers. Afr J Biotechnol 10:6001-6010

Eppendorfer WH, Eggum BO (1994) Effects of sulphur, nitrogen, phosphorus, potassium, and water stress on dietary fibre fractions, starch, amino acids and on the biological value of potato protein. Plant Foods Hum Nutr 45:299-313. https://doi.org/10.1007/BF01088079

Errebhi M, Rosen CJ, Gupta SC, Birong DE (1998) Potato yield response and nitrate leaching as influenced by nitrogen management. Agron J 90:10-15. https://doi.org/10.2134/agronj1998.00021962009000010003x

Evans LT, Fischer RA (1999) Yield potential: its definition, measurement, and significance. Crop Sci 39: 1544-1551. https://doi.org/10.2135/cropsci1999.3961544x

Eves-van den Akker S, Laetsch DR, Thorpe P, Lilley CJ, Danchin EGJ, Da Rocha M, Rancurel C, Holroyd NE, Cotton JA, Szitenberg A, Grenier E, Montarry J, Mimee B, Duceppe M-O, Boyes I, Marvin JMC, Jones LM, Yusup HB, Lafond-Lapalme J, Esquibet M, Sabeh M, Rott M, Overmars H, Finkers-Tomczak A, Smant G, Koutsovoulos G, Blok V, Mantelin S, Cock PJA, Phillips W, Henrissat B, Urwin PE, Blaxter M, Jones JT (2016) The genome of the yellow potato cyst nematode, Globodera rostochiensis, reveals insights into the basis of parasitism and virulence. Genome Biol 17:124. https://doi.org/10.1186/s13059016-0985-1

Fageria VD (2001) Nutrient interactions in crop plants. J Plant Nutr 24:1269-1290. https://doi.org/10.1081 /PLN-100106981

FPVO (2018) Federal Plant Variety Office. Descriptive Variety List Potatoes 2018. https://www. bundessortenamt.de/bsa/media/Files/BSL/bsl_kartoffel_2018.pdf. Accessed 6 June 2019

Galili G, Amir R (2013) Fortifying plants with the essential amino acids lysine and methionine to improve nutritional quality. Plant Biotechnol J 11:211-222. https://doi.org/10.1111/pbi.12025

Gerardeaux E, Jordan-Meille L, Constantin J, Pellerin S, Dingkuhn M (2010) Changes in plant morphology and dry matter partitioning caused by potassium deficiency in Gossypium hirsutum (L.). Environ Exp Bot 67:451-459. https://doi.org/10.1016/j.envexpbot.2009.09.008

Gerendás J, Heuser F, Sattelmacher B (2007) Influence of nitrogen and potassium supply on contents of acrylamide precursors in potato tubers and on acrylamide accumulation in french fries. J Plant Nutr 30: 1499-1516. https://doi.org/10.1080/01904160701555846

Gransee A, Führs H (2013) Magnesium mobility in soils as a challenge for soil and plant analysis, magnesium fertilization and root uptake under adverse growth conditions. Plant Soil 368:5-21. https://doi. org/10.1007/s11104-012-1567-y

Grant CA, Flaten DN, Tomasiewicz DJ, Sheppard SC (2001) The importance of early season phosphorus nutrition. Can J Plant Sci 81:211-224

Hawker JS, Marschner H, Krauss A (1979) Starch synthesis in developing potato tubers. Physiol Plant 46:2530. https://doi.org/10.1111/j.1399-3054.1979.tb03180.x

Haynes RJ (1990) Active ion uptake and maintenance of cation-anion balance: a critical examination of their role in regulating rhizosphere $\mathrm{pH}$. Plant Soil 126:247-264. https://doi.org/10.1007/bf00012828 
Herman DJ, Knowles LO, Knowles NR (2017) Heat stress affects carbohydrate metabolism during coldinduced sweetening of potato (Solanum tuberosum L.). Planta 245:563-582. https://doi.org/10.1007 /s00425-016-2626-Z

Hermans C, Bourgis F, Faucher M, Strasser RJ, Delrot S, Verbruggen N (2005) Magnesium deficiency in sugar beets alters sugar partitioning and phloem loading in young mature leaves. Planta 220:541-549. https://doi.org/10.1007/s00425-004-1376-5

Hopkins BG (2013) Russet Burbank potato phosphorus fertilization with dicarboxylic acid copolymer additive (AVAIL®). J Plant Nutr 36:1287-1306. https://doi.org/10.1080/01904167.2013.785565

Hopkins BG, Ellsworth JW, Bowen TR, Cook AG, Stephens SC, Jolley VD, Shiffler AK, Eggett D (2010) Phosphorus fertilizer timing for Russet Burbank potato grown in calcareous soil. J Plant Nutr 33:529-540. https://doi.org/10.1080/01904160903506266

Hopkins BG, Horneck DA, MacGuidwin AE (2014) Improving phosphorus use efficiency through potato rhizosphere modification and extension. Am J Potato Res 91:161-174. https://doi.org/10.1007/s12230014-9370-3

Hoppo SD, Elliott DE, Reuter DJ (1999) Plant tests for diagnosing phosphorus deficiency in barley (Hordeum vulgare L.). Aust J Exp Agric 39:857-872. https://doi.org/10.1071/Ea99029

Horneck D, Rosen C (2008) Measuring nutrient accumulation rates of potatoes - tools for better management. Better Crops 92:4-6

Hütsch BW, Keipp K, Glaser A-K, Schubert S (2018) Potato plants (Solanum tuberosum L.) are chloridesensitive: is this dogma valid? J Sci Food Agric 98:3161-3168. https://doi.org/10.1002/jsfa.8819

Imsande J (1998) Iron, sulfur, and chlorophyll deficiencies: a need for an integrative approach in plant physiology. Physiol Plant 103:139-144. https://doi.org/10.1034/j.1399-3054.1998.1030117.x

Iwama K (2008) Physiology of the potato: new insights into root system and repercussions for crop management. Potato Res 51:333-353. https://doi.org/10.1007/s11540-008-9120-3

Izmirlioglu G, Demirci A (2015) Enhanced bio-ethanol production from industrial potato waste by statistical medium optimization. Int J Mol Sci 16:24490-24505. https://doi.org/10.3390/ijms161024490

Jackson SD (1999) Multiple signaling pathways control tuber induction in potato. Plant Physiol 119:1-8. https://doi.org/10.1104/pp.119.1.1

Jagatee S, Behera S, Dash PK, Sahoo S, Mohanty RC (2015) Bioprospecting starchy feedstocks for bioethanol production: a future perspective. JMRR 3:24-42

Jákli B, Tränkner M, Senbayram M, Dittert K (2016) Adequate supply of potassium improves plant water-use efficiency but not leaf water-use efficiency of spring wheat. J Plant Nutr Soil Sci 179:733-745. https://doi. org/10.1002/jpln.201600340

Jansen MAK (2002) Ultraviolet-B radiation effects on plants: induction of morphogenic responses. Physiol Plant 116:423-429. https://doi.org/10.1034/j.1399-3054.2002.1160319.x

Jarvis MC (1984) Structure and properties of pectin gels in plant-cell walls. Plant Cell Environ 7:153-164. https://doi.org/10.1111/1365-3040.ep11614586

Jenkins PD, Ali H (2000) Phosphate supply and progeny tuber numbers in potato crops. Ann Appl Biol 136: 41-46. https://doi.org/10.1111/j.1744-7348.2000.tb00007.x

Kang W, Fan M, Ma Z, Shi X, Zheng H (2014) Luxury absorption of potassium by potato plants. Am J Potato Res 91:573-578. https://doi.org/10.1007/s12230-014-9386-8

Karam F, Rouphael Y, Lahoud R, Breidi J, Colla G (2009) Influence of genotypes and potassium application rates on yield and potassium use efficiency of potato. J Agron 8:27-32. https://doi.org/10.3923 /ja.2009.27.32

Kärenlampi SO, White PJ (2009) Chapter 5-potato proteins, lipids, and minerals. In: Singh J, Kaur L (eds) Advances in potato chemistry and technology. Elsevier, Amsterdam, pp 99-125

Kelling KA, Hensler RF, Speth PE (2015) Importance of early-season nitrogen rate and placement to Russet Burbank potatoes. Am J Potato Res 92:502-510. https://doi.org/10.1007/s12230-015-9464-6

King JC, Slavin JL (2013) White potatoes, human health, and dietary guidance. Adv Nutr 4:393S-401S. https://doi.org/10.3945/an.112.003525

Kirkby EA, Pilbeam DJ (1984) Calcium as a plant nutrient. Plant Cell Environ 7:397-405. https://doi. org/10.1111/j.1365-3040.1984.tb01429.x

Klikocka H, Haneklaus S, Bloem E, Schnug E (2005) Influence of sulfur fertilization on infection of potato tubers with Rhizoctonia solani and Streptomyces scabies. J Plant Nutr 28:819-833. https://doi. org/10.1081/PLN-200055547

Koch M, Busse M, Naumann M, Jákli B, Smit I, Cakmak I, Hermans C, Pawelzik E (2019a) Differential effects of varied potassium and magnesium nutrition on production and partitioning of photoassimilates in potato plants. Physiol Plant. https://doi.org/10.1111/ppl.12846 
Koch M, Naumann M, Pawelzik E (2019b) Cracking and fracture properties of potato (Solanum tuberosum L.) tubers and their relation to dry matter, starch, and mineral distribution. J Sci Food Agric 99:31493156. https://doi.org/10.1002/jsfa.9530

Koprivova A, Kopriva S (2016) Sulfur metabolism and its manipulation in crops. J Genet Genomics 43:623629. https://doi.org/10.1016/j.jgg.2016.07.001

Kratzke MG, Palta JP (1985) Evidence for the existence of functional roots on potato tubers and stolons: significance in water transport to the tuber. Am Potato J 62:227-236. https://doi.org/10.1007 /BF02852802

Kumar P, Pandey SK, Singh BP, Singh SV, Kumar D (2007) Influence of source and time of potassium application on potato growth, yield, economics and crisp quality. Potato Res 50:1-13. https://doi. org/10.1007/s11540-007-9023-8

Lazarević B, Horvat T, Poljak M (2014) Effect of acid aluminous soil on photosynthetic parameters of potato (Solanum tuberosum L.). Potato Res 57:33-46. https://doi.org/10.1007/s11540-014-9251-7

Legge RL, Thompson JE, Baker JE, Lieberman M (1982) The effect of calcium on the fluidity and phase properties of microsomal-membranes isolated from post-climacteric golden delicious apples. Plant Cell Physiol 23:161-169. https://doi.org/10.1093/oxfordjournals.pcp.a076335

Leigh R, Wyn Jones R (1984) A hypothesis relating critical potassium concentrations for growth to the distribution and functions of this ion in the plant cell. New Phytol 97:1-13. https://doi.org/10.1111/j.14698137.1984.tb04103.x

Liu H-Y, Sun W-N, Su W-A, Tang Z-C (2006) Co-regulation of water channels and potassium channels in rice. Physiol Plant 128:58-69. https://doi.org/10.1111/j.1399-3054.2006.00709.x

Liu C, Rubæk GH, Liu F, Andersen MN (2015) Effect of partial root zone drying and deficit irrigation on nitrogen and phosphorus uptake in potato. Agric Water Manag 159:66-76. https://doi.org/10.1016/j. agwat.2015.05.021

Maier NA, McLaughlin MJ, Heap M, Butt M, Smart MK (2002) Effect of current-season application of calcitic lime and phosphorus fertilization on soil $\mathrm{pH}$, potato growth, yield, dry matter content, and cadmium concentration. Commun Soil Sci Plant Anal 33:2145-2165. https://doi.org/10.1081/CSS120005754

Marschner P (2012) Marschner's mineral nutrition of higher plants. Elsevier, Amsterdam

Mauromicale G, Ierna A, Marchese M (2006) Chlorophyll fluorescence and chlorophyll content in fieldgrown potato as affected by nitrogen supply, genotype, and plant age. Photosynthetica 44:76-82. https://doi.org/10.1007/s11099-005-0161-4

McAinsh MR, Pittman JK (2009) Shaping the calcium signature. New Phytol 181:275-294. https://doi. org/10.1111/j.1469-8137.2008.02682.x

McNabnay M, Dean BB, Bajema RW, Hyde GM (1999) The effect of potassium deficiency on chemical, biochemical and physical factors commonly associated with blackspot development in potato tubers. Am J Potato Res 76:53-60. https://doi.org/10.1007/BF02855200

McNall P (1933) The law of diminishing returns in agriculture. J Agric Res 47:167-178

Mengel K, Kirkby E (2001) Principles of plant nutrition. Springer, Dordrecht

Michel A, Sinton SM, Falloon RE, Shah FA, Dellow SJ, Pethybridge SJ (2015) Biotic and abiotic factors affecting potato yields in Canterbury, New Zealand. In: Proceedings of the 17th ASA conference, Hobart, Australia, pp 211-214

Nijland GO, Schouls J, Goudriaan J (2008) Integrating the production functions of Liebig, Michaelis-Menten, Mitscherlich and Liebscher into one system dynamics model. NJAS 55:199-224. https://doi.org/10.1016 /S1573-5214(08)80037-1

Nowicki M, Fooled MR, Nowakowska M, Kozik EU (2012) Potato and tomato late blight caused by phytophthora infestans: an overview of pathology and resistance breeding. APS 96:4-17. https://doi. org/10.1094/Pdis-05-11-0458

Obidiegwu JE, Bryan GJ, Jones HG, Prashar A (2015) Coping with drought: stress and adaptive responses in potato and perspectives for improvement. Front Plant Sci 6:542. https://doi.org/10.3389/fpls.2015.00542

Ojala JC, Stark JC, Kleinkopf GE (1990) Influence of irrigation and nitrogen management on potato yield and quality. Am Potato J 67:29-43. https://doi.org/10.1007/BF02986910

Olivier M, Goffart J-P, Ledent J-F (2006) Threshold value for chlorophyll meter as decision tool for nitrogen management of potato. Agron J 98:496-506. https://doi.org/10.2134/agronj2005.0108

Ospina CA, Lammerts van Bueren ET, Allefs JJHM, Engel B, van der Putten PEL, van der Linden CG, Struik PC (2014) Diversity of crop development traits and nitrogen use efficiency among potato cultivars grown under contrasting nitrogen regimes. Euphytica 199:13-29. https://doi.org/10.1007/s10681-014-1203-4 
Oufir M, Legay S, Nicot N, Van Moer K, Hoffmann L, Renaut J, Hausman J-F, Evers D (2008) Gene expression in potato during cold exposure: changes in carbohydrate and polyamine metabolisms. Plant Sci 175:839-852. https://doi.org/10.1016/j.plantsci.2008.08.010

Ozgen S, Karlsson BH, Palta JP (2006) Response of potatoes (cv Russet Burbank) to supplemental calcium applications under field conditions: tuber calcium, yield, and incidence of internal brown spot. Am J Potato Res 83:195-204. https://doi.org/10.1007/bf02872155

Palta JP (2010) Improving potato tuber quality and production by targeted calcium nutrition: the discovery of tuber roots leading to a new concept in potato nutrition. Potato Res 53:267-275. https://doi.org/10.1007 /s11540-010-9163-0

Panique E, Kelling KA, Schulte EE, Hero DE, Stevenson WR, James RV (1997) Potassium rate and source effects on potato yield, quality, and disease interaction. Am Potato J 74:379-398. https://doi.org/10.1007 /bf02852777

Perrenoud S (1993) Fertilising for high yield potato. IPI-bulletin 8. International Potash Institute, Berne

Petersen SO, Sommer SG (2011) Ammonia and nitrous oxide interactions: roles of manure organic matter management. Anim Feed Sci Technol 166-167:503-513. https://doi.org/10.1016/j.anifeedsci.2011.04.077

Porter GA, Sisson JA (1991) Petiole nitrate content of Maine-grown Russet Burbank and Shepody potatoes in response to varying nitrogen rate. Am Potato J 68:493-505. https://doi.org/10.1007/BF02853766

Pote DH, Daniel TC, Moore PA, Nichols DJ, Sharpley AN, Edwards DR (1996) Relating extractable soil phosphorus to phosphorus losses in runoff. Soil Sci Soc Am J 60:855-859. https://doi.org/10.2136 /sssaj1996.03615995006000030025x

Pottosin II, Schonknecht G (2007) Vacuolar calcium channels. J Exp Bot 58:1559-1569. https://doi. org/10.1093/jxb/erm035

Qadri RWK, Khan I, Jahangir MM, Ashraf U, Samin G, Anwer A, Adnan M, Bashir M (2015) Phosphorous and foliar applied nitrogen improved productivity and quality of potato. Am J Plant Sci 6:144-149. https://doi.org/10.4236/ajps.2015.61016

Raghothama KG (2000) Phosphate transport and signaling. Curr Opin Plant Biol 3:182-187. https://doi. org/10.1016/S1369-5266(00)80063-1

Rens L, Zotarelli L, Alva A, Rowland D, Liu G, Morgan K (2016a) Fertilizer nitrogen uptake efficiencies for potato as influenced by application timing. Nutr Cycl Agroecosyst 104:175-185. https://doi.org/10.1007 /s10705-016-9765-2

Rens LR, Zotarelli L, Cantliffe DJ, Stoffella PJ, Gergela D, Burhans D (2016b) Commercial evaluation of seasonal distribution of nitrogen fertilizer for potato. Potato Res 59:1-20. https://doi.org/10.1007/s11540015-9304-6

Rich AE (1983) Potato diseases. Academic Press, London

Roberts S, Beaton JD (1988) Potato use of phosphorus and potassium in sandy soils. https://research.libraries. wsu.edu/xmlui/bitstream/handle/2376/5239/xb1004e.pdf?sequence=1. Accessed 6 June 2019

Rosen CJ, Kelling KA, Stark JC, Porter GA (2014) Optimizing phosphorus fertilizer management in potato production. Am J Potato Res 91:145-160. https://doi.org/10.1007/s12230-014-9371-2

Rumberg B, Siggel U (1969) pH changes in the inner phase of the thylakoids during photosynthesis. Naturwissenschaften 56:130-132

Schilling G, Eißner H, Schmidt L, Peiter E (2016) Yield formation of five crop species under water shortage and differential potassium supply. J Plant Nutr Soil Sci 179:234-243. https://doi.org/10.1002 /jpln.201500407

Senbayram M, Gransee A, Wahle V, Thiel H (2015) Role of magnesium fertilisers in agriculture: plant-soil continuum. Crop Pasture Sci 66:1219-1229. https://doi.org/10.1071/CP15104

Shabala S, Pottosin I (2014) Regulation of potassium transport in plants under hostile conditions: implications for abiotic and biotic stress tolerance. Physiol Plant 151:257-279. https://doi.org/10.1111/ppl.12165

Sharma UC, Arora BR (1988) Effect of applied nutrients on the starch, proteins and sugars in potatoes. Food Chem 30:313-317. https://doi.org/10.1016/0308-8146(88)90116-1

Sharma D, Kushwah S, Nema P, Rathore S (2011) Effect of sulphur on yield and quality of potato (Solanum tuberosum L.). Int J Agric Res 6:143-148. https://doi.org/10.3923/ijar.2011.143.148

Silva JG, França MGC, Gomide FTF, Magalhaes JR (2013) Different nitrogen sources affect biomass partitioning and quality of potato production in a hydroponic system. Am J Potato Res 90:179-185. https://doi.org/10.1007/s12230-012-9297-5

Smith SJ, van Aardenne J, Klimont Z, Andres RJ, Volke A, Delgado Arias S (2011) Anthropogenic sulfur dioxide emissions: 1850-2005. Atmos Chem Phys 11:1101-1116. https://doi.org/10.5194/acp-11-11012011 
Sperrazza JM, Spremulli LL (1983) Quantitation of cation binding to wheat germ ribosomes: influences on submit association equilibria and ribosome activity. Nucleic Acids Res 11:2665-2679. https:/doi. org/10.1093/nar/11.9.2665

Spillman W (1923) Application of the law of diminishing returns to some fertilizer and feed data. Am J Agric Econ 5:36-52. https://doi.org/10.2307/1230266

Sprengel C (1828) Von den Substanzen der Ackerkrume und des Untergrundes. Journal für Technische und Ökonomische Chemie 2:423-474

Stark JC, Hopkins BG (2015) Fall and spring phosphorus fertilization of potato using a dicarboxylic acid polymer (AVAIL®). J Plant Nutr 38:1595-1610. https://doi.org/10.1080/01904167.2014.983124

Stark JC, Westermann DT, Hopkins B (2004) Nutrient management guidelines for Russet Burbank potatoes. University of Idaho. http://www.extension.uidaho.edu/Nutrient/pdf/Potato/Nutrient\%20Management\%20 Guidelines\%20for\%20Russet\%20Burbank\%20Potatoes.pdf. Accessed 6 June 2019

Strebel O, Duynisveld WHM (1989) Nitrogen supply to cereals and sugar beet by mass flow and diffusion on a silty loam soil. J Plant Nutr Soil Sci 152:135-141. https://doi.org/10.1002/jpln.19891520202

Subramanian NK, White PJ, Broadley MR, Ramsay G (2011) The three-dimensional distribution of minerals in potato tubers. Ann Bot 107:681-691. https://doi.org/10.1093/aob/mcr009

Tiemens-Hulscher M, Lammerts van Bueren ET, Struik PC (2014) Identifying nitrogen-efficient potato cultivars for organic farming. Euphytica 199:137-154. https://doi.org/10.1007/s10681-014-1143-Z

van der Ploeg RR, Böhm W, Kirkham MB (1999) On the origin of the theory of mineral nutrition of plants and the law of the minimum. Soil Sci Soc Am J 63:1055-1062. https://doi.org/10.2136/sssaj1999.6351055x

Van Keulen H, Stol W (1995) Agro-ecological zonation for potato production. In: Haverkort AJ, MacKerron DKL (eds) Potato ecology and modelling of crops under conditions limiting growth. Springer, Amsterdam, pp 357-371

van Lierop W, Tran TS, Banville G, Morissette S (1982) Effect of liming on potato yields as related to soil pH, Al, Mn, and Ca. Agron J 74:1050-1055. https://doi.org/10.2134/agronj1982.00021962007400060028x

Verbruggen N, Hermans C (2013) Physiological and molecular responses to magnesium nutritional imbalance in plants. Plant Soil 368:87-99. https://doi.org/10.1007/s11104-013-1589-0

von Liebig JF (1840) Die organische Chemie in ihrer Anwendung auf Agricultur und Physiologie. Vieweg, Braunschweig

von Liebig JF (1855) Die Grundsätze der Agricultur-Chemie. Mit Rücksicht auf die in England angestellten Untersuchungen. Vieweg, Braunschweig

Vos J (1995) Nitrogen and the growth of potato crops. In: Haverkort AJ, MacKerron DKL (eds) Potato ecology and modelling of crops under conditions limiting growth. Springer, Amsterdam, pp 115-128

Vos J (2009) Nitrogen responses and nitrogen management in potato. Potato Res 52:305-317. https://doi. org/10.1007/s11540-009-9145-2

Vos J, van der Putten PEL (1998) Effect of nitrogen supply on leaf growth, leaf nitrogen economy and photosynthetic capacity in potato. Field Crops Res 59:63-72. https://doi.org/10.1016/S0378-4290(98 )00107-5

Walker CJ, Weinstein JD (1994) The magnesium-insertion step of chlorophyll biosynthesis is a two-stage reaction. Biochem J 299:277-284. https://doi.org/10.1042/bj2990277

Walker DJ, Leigh RA, Miller AJ (1996) Potassium homeostasis in vacuolate plant cells. PNAS 93:1051010514. https://doi.org/10.1073/pnas.93.19.10510

Wang Y, Wu W-H (2013) Potassium transport and signaling in higher plants. Annu Rev Plant Biol 64:451476. https://doi.org/10.1146/annurev-arplant-050312-120153

Wang-Pruski G, Nowak J (2004) Potato after-cooking darkening. Am J Potato Res 81:7-16. https://doi. org/10.1007/bf02853831

Waterer D (2002) Impact of high soil $\mathrm{pH}$ on potato yields and grade losses to common scab. Can J Plant Sci 82:583-586. https://doi.org/10.4141/P01-046

Westermann D, Tindall T (1995) Managing potassium in potato production systems of Idaho. In: Proceedings of the Winter Commodity Schools, pp 201-207

Whalley HJ, Knight MR (2013) Calcium signatures are decoded by plants to give specific gene responses. New Phytol 197:690-693. https://doi.org/10.1111/nph.12087

White PJ, Broadley MR (2003) Calcium in plants. Ann Bot 92:487-511. https://doi.org/10.1093/aob/mcg164

White PJ, Broadley MR (2009) Biofortification of crops with seven mineral elements often lacking in human diets - iron, zinc, copper, calcium, magnesium, selenium and iodine. New Phytol 182:49-84. https://doi. org/10.1111/j.1469-8137.2008.02738.x

White PJ, Bradshaw JE, Finlay M, Dale B, Ramsay G, Hammond JP, Broadley MR (2009) Relationships between yield and mineral concentrations in potato tubers. Hortic Sci 44:6-11. https://doi.org/10.21273 /HORTSCI.44.1.6 
Withers PJA, Haygarth PM (2007) Agriculture, phosphorus and eutrophication: a European perspective. Soil Use Manag 23:1-4. https://doi.org/10.1111/j.1475-2743.2007.00116.x

Wolfe DW, Fereres E, Voss RE (1983) Growth and yield response of two potato cultivars to various levels of applied water. Irrig Sci 3:211-222. https://doi.org/10.1007/BF00272837

Woodrow IE, Berry JA (1988) Enzymatic regulation of photosynthetic $\mathrm{CO}_{2}$ fixation in C3 plants. Annu Rev Plant Physiol Plant Mol Biol 39:533-594. https://doi.org/10.1146/annurev.arplant.39.1.533

Wulff F, Schulz V, Jungk A, Claassen N (1998) Potassium fertilization on sandy soils in relation to soil test, crop yield and K-leaching. J Soil Sci Plant Nut 161:591-599. https://doi.org/10.1002 /jpln.1998.3581610514

Yuguan Z, Min Z, Luyang L, Zhe J, Chao L, Sitao Y, Yanmei D, Na L, Fashui H (2009) Effects of cerium on key enzymes of carbon assimilation of spinach under magnesium deficiency. Biol Trace Elem Res 131: 154-164. https://doi.org/10.1007/s12011-009-8354-5

Zebarth BJ, Rosen CJ (2007) Research perspective on nitrogen bmp development for potato. Am J Potato Res 84:3-18. https://doi.org/10.1007/BF02986294

Zebarth BJ, Bélanger G, Cambouris AN, Ziadi N (2012) Nitrogen fertilization strategies in relation to potato tuber yield, quality, and crop N recovery. In: He Z, Larkin R, Honeycutt W (eds) Sustainable potato production: global case studies. Springer, Amsterdam, pp 165-186

Zhang JL, George E (2002) Changes in the extractability of cations (Ca, Mg and $\mathrm{K}$ ) in the rhizosphere soil of Norway spruce (Picea abies) roots. Plant Soil 243:209-217. https://doi.org/10.1023/A:1019915512072

Zörb C, Senbayram M, Peiter E (2014) Potassium in agriculture - status and perspectives. J Plant Physiol 171: 656-669. https://doi.org/10.1016/j.jplph.2013.08.008

Zorn W, Marks G, Heß H, Bergmann W (2016) Handbuch zur visuellen Diagnose von Ernährungsstörungen bei Kulturpflanzen. Elsevier, Amsterdam

Publisher's Note Springer Nature remains neutral with regard to jurisdictional claims in published maps and institutional affiliations. 